\title{
Evaluation of BOD and DO for Diyala River by Using Stream Water Quality Model
}

\author{
G. A. AL-Dulaimi
}

\begin{abstract}
This paper was studied the biochemical parameter (BOD5) and (DO) for Diyala River (Iraq) which regard significant tributary for the Tigris River. Water samples have been collected from Diyala River along different points between Baquba to Al-Zafarania and were analyzed for various water quality parameters during low flow season (November). The study involves application of stream water quality model QUAL2K model to simulate and predict the dissolved oxygen (DO) and biochemical oxygen demand (BOD5) profiles for Diyala River in a stretch of 251 kilometer. Model output showed that DO in the entire river was within limit of not less than $4 \mathrm{mg} / \mathrm{L}$. For Carbonaceous Biochemical Oxygen Demand CBOD, the entire river may be divided into three main reaches; first one is extended from Kalar City $(0 \mathrm{~km})$ to Jalawla $(46 \mathrm{~km})$ and have CBOD concentration of $2 \mathrm{mg} / \mathrm{L}$, the second reach has CBOD range (2-4) $\mathrm{mg} / \mathrm{L}$ in which begins from Sadiyah city and extend to near Buhriz city city $(168 \mathrm{~km})$, the third reach extends from Khan Bani Saad city to Al-Zafaraniah $(251 \mathrm{~km})$ in the south east of Baghdad city confluence point with Tigris River which has CBOD concentrations of more than $5 \mathrm{mg} / \mathrm{L}$.
\end{abstract}

Index Terms - BOD, COD, Diyala river.

\section{INTRODUCTION}

The wastewater disposal generated from municipal and industrial sources without adequate treatment prior to discharge is current practice in most developing countries [1]. Diyala River basin is located between Latitude (33 $13^{\circ} 00^{\prime \prime}$ N- $35^{\circ} 50^{\prime} 00^{\prime \prime} \mathrm{N}$ ) and Longitude ( $44^{\circ} 30^{\prime} 00^{\prime \prime} \mathrm{E}-45^{\circ} 20^{\prime} 00^{\prime \prime}$ E), and passes through Diyala province northeast of Baghdad. Diyala River is one of the main water resources of Iraq and one of the most important tributaries of Tigris River in Iraq [1]. For this reason many cities are situated on its banks, as well as, wastes fluids of agricultural and industrial activities in these cities are also concentrated directly to this river. It drains an area of about $32600 \mathrm{~km} 2$ lying across Iraqi-Iranian frontiers. The river basin is widely varied through the entire catchments area from semi-arid plain north of Baghdad to mountainous area of western Iran [1]. The Upper and Middle Diyala lie within the folded zone in which the cretaceous strata are exposed, as well as Mukdadiya, Fatha formations and Quaternary terraces are dispersed. Lower Diyala is covered mainly by recent alluvium and lies within the unfolded zone. The Climatic conditions vary so much in the river catchments in which the rainy season starting from November to April, the annual amount of precipitation varies from $800 \mathrm{~mm}$ near the northern parts to $250 \mathrm{~mm}$ near southern limits of the basin. The annual evaporation rate may reach as high as $2000 \mathrm{~mm} /$ year [1]. These conditions have

Manuscript received February 24, 2017; revised June 1, 2017.

G. A. AL-Dulaimi is with the Philadelphia University, Jordan (e-mail: galdulaimi@philadelphia.edu.jo). clear effects on alteration of wet and dry years and then on the variation of river water quality. However, the catchments area of Diyala river are lies within highly cultivated regions and have many canals and drainage channels, which contributing and affects river hydrochemistry. The Diyala River basin is one of these basins, which cover the important parts of Iraq and its impact in the quality of the waters of the Tigris, which meets the latter south of Baghdad [1].

Strategy of the water quality management may involve a series of complex inter-disciplinary decisions based on expect responses of water quality to changing controls. Mathematical models are described the complex relationships between waste loads from different sources and the resulting water qualities of the receiving waters. A suitable water quality model which can simulate the river system is essential to the water quality management of Diyala River. The most widely used mathematical model for conventional pollutant impact evaluation is QUAL2E [2] developed by United States Environmental Protection Agency (US EPA). However, several limitations of the QUAL2E have been reported [3]. One of the major inadequacies is the lack of provision for conversion of algal death to carbonaceous biochemical oxygen demand [4]. Now, USEPA has released a new version model, QUAL2K [5] to represent a modernized version of the QUAL2E model. QUAL2K model included the addition of new water quality interactions, such as conversion of algal death to BOD, denitrification, and DO change caused by fixed plants and, these new elements can overcome limitations of QUAL2E. Paliwal [6] have simulated the BOD and DO concentration in Yamuna River at Delhi using QUAL2E model. They had showed four different pollution scenarios to manage the water quality in the river. Their results were wide acceptance with literature studies conducted on the river. Kannel [7] has used QUAL2Kw model to simulate various water quality management strategies during the critical period for Bagmati River in Kathmandu Valley (Nepal). They stated that the local oxygenation is effective to maintain minimum DO concentrations in the river. QUAL2K is one-dimensional, steady flow stream water quality model and thus its application is limited to steady state flow condition. It has many new elements. It includes DO interaction with fixed plants, conversion of algal death to CBOD and reduction of amount of CBOD due to de-nitrification. It is useful in data limited conditions and is freely available. A real situation of a river can be represented more closely using complex models. However, the complex models, such as $2 \mathrm{D}$ or $3 \mathrm{D}$, are highly sophisticated and are usually reserved for large (i.e. deep and wide) rivers/estuaries where the mixing patterns are complex and require large amount of data [7]. Diyala River-reach being simulated with respect to the mixing length 
over the cross-section and the transport is dominated by longitudinal changes [7]. Thus, the assumption of 1D process is valid. Hence QUAL2K was chosen as a framework of water quality modelling in this paper, the utilization of QUAL2K as a complete decision-making package has been studied to predict the DO and BOD5 concentration in the Diyala river along three parts.

\section{MAterials AND MethodS}

The methodology of this research involves two main aspects, firstly field sampling and laboratory work .Secondly include run the stream water quality model. Following the procedure that has been used in this research.

\section{A. Field Sampling and Laboratory Methods}

For this study numerous stations had been sampled and same procedure has been used for water sampling from Abdullah [1]. Ten water samples were collected from the study area during November 2015. The samples covered the study area from Kalar city to the confluence point with Tigris River at Baghdad city, Fig. 1. The samples were collected at $10-15 \mathrm{~cm}$ depth in separate pre-conditioned and acid rinsed clean polypropylene bottles The collected samples were filtered (Whatman no. 42) and acidified with concentrated nitric acid to a $\mathrm{pH}$ below 2.0 to minimize precipitation and adsorption on container walls[1]. The polypropylene bottles were used for water quality parameter analysis. Water samples for BOD estimation were collected in BOD bottles (non-reactive borosilicate glass bottles of $300 \mathrm{ml}$ capacity). Analysis of water samples was started as soon as possible after collection to avoid unpredictable changes. The bottles were kept at $+4^{\circ} \mathrm{C}$ and analyzed within approximately $24 \mathrm{~h}$. The analysis of the samples was done at chemical laboratory of water resource techniques department, institute of technology. The selected parameters included water Temperature, $\mathrm{pH}$, electrical conductivity (EC), five days biochemical oxygen demand (BOD5), Dissolved oxygen (DO) and total alkalinity (TA).

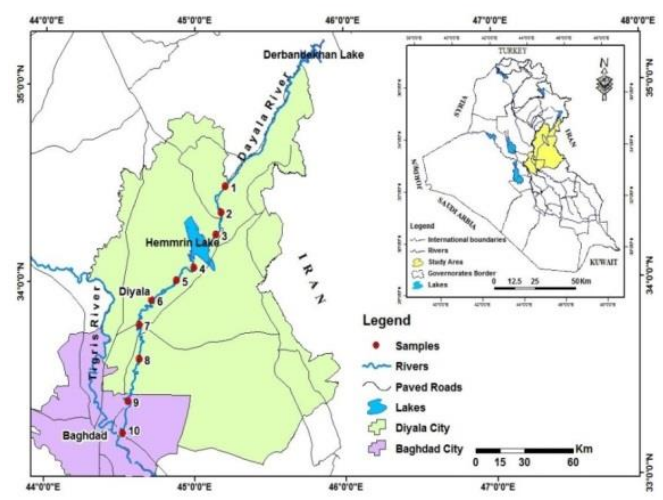

Fig. 1. Description of study area with sampling locations

\section{B. Remote Sensing and GIS Technique}

A Satellite image of Landsat7-ETM (2014) corrected by used ERDAS 9.2 has been used in this research. The satellite data was visually interoperated and accuracy was checked on the ground. Digital Elevation Model (DEM) was created using Global Mapper.11, Fig. 2. , the DEM has been used to predict the hydraulic parameter for the Diyala River such as longitudinal slope, exacts location for the sample which inter them into QUAL2K model to get the result. The DEM shows there were a significant variation in elevation from 65 meter above sea level in the first segment to the $30 \mathrm{~m}$ in the last segment.

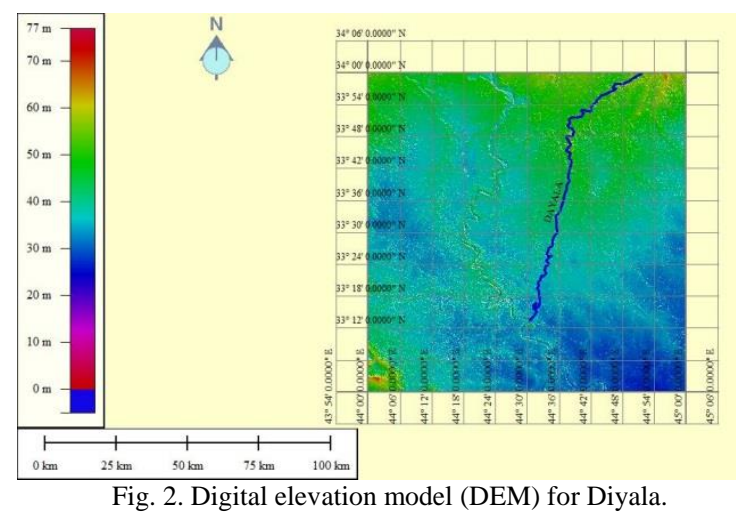

\section{Stream Water Quality Model}

QUAL2K is a river and stream water quality model and is modernized version of the QUAL2E. The following features characterize QUAL2K: [5] (i) one dimensional (the channel is well-mixed vertically and laterally); (ii) steady-state hydraulics (non-uniform, steady flow is simulated); (iii) diurnal heat budget (the heat budget and temperature are simulated as a function of meteorology on a diurnal time scale); (iv) diurnal water-quality kinetics (all water-quality variables are simulated on a diurnal time scale); (v) Heat and mass inputs (point and non-point loads and abstractions are simulated). In the QUAL2K model the River is divided into several reaches and each reach divided into segments. These segments are model's shortest parts of simulation. A steady-state flow balance is implemented for each model reach:

$$
\text { Qi }=\text { Qi }-1+\text { Qin, } \mathrm{i}-\mathrm{Qab}, \mathrm{I}
$$

where Qi is outflow from reach i into reach $\mathrm{i}+1, \mathrm{~m} 3 / \mathrm{d}$; Qi-1 is inflow from the upstream reach $\mathrm{i}-1, \mathrm{~m} 3 / \mathrm{d}$; Qin, $\mathrm{i}$ is the total inflow into the reach from point and non-point sources, $\mathrm{m} 3 / \mathrm{d}$; and Qab,i is the total outflow from the reach due to point and non-point abstractions, $\mathrm{m} 3 / \mathrm{d}$.

Once the outflow for each reach is computed, the depth and velocity are calculated in one of three ways: weirs, rating curves, and Manning equations. In this study, each river reach is idealized as a trapezoidal channel [8]. Under conditions of steady flow, the Manning equation can be used to express the relationship between flow and depth as:

$$
Q=\frac{S_{0}^{0.5}}{n} \times \frac{A_{C}^{5 / 3}}{P^{0.67}}
$$

where $\mathrm{Q}=$ flow $[\mathrm{m} 3 / \mathrm{sec}]$; So $=$ bottom longitudinal slope $[\mathrm{m} / \mathrm{m}] ; \mathrm{n}=$ Manning roughness coefficient; Ac = cross sectional area $[\mathrm{m} 2]$; and $\mathrm{P}=$ wetted perimeter $[\mathrm{m}]$. This model can simulate fate and transport of so many parameters and contaminants including temperature, $\mathrm{pH}$, carbonaceous biochemical demand, sediment oxygen demand, dissolved oxygen, various kinds of nutrients, phytoplankton and bottom algae. In this study, DO and BOD are considered for modeling their concentration in the river. The modeling tool QUAL2K has a general mass balance equation for a 
constituent concentration in the water column of a reach $i$ (the transport and loading terms are omitted from the mass balance equation for bottom algae modeling) as: [9]

$$
\begin{gathered}
\frac{d_{c i}}{d_{t}}=\frac{Q_{i-1}}{v_{i}} C_{i-1}-\frac{Q_{i}}{V_{i}}-\frac{Q_{a b, i}}{v_{i}} C_{i}+\frac{E_{i-1}}{V_{i}}\left(C_{i-1}-C_{i}\right)+ \\
\frac{E_{i}}{V_{i}}\left(C_{i-1}-C_{i}\right)+\frac{W_{i}}{V_{i}}+S_{i}
\end{gathered}
$$

where $\mathrm{Ci}$ is variable concentration for reach $\mathrm{i}, \mathrm{g} / \mathrm{m} 3$; $\mathrm{t}$ is time, $\mathrm{d}$; Qi is outflow from reach $\mathrm{i}$ into reach $\mathrm{i}+1, \mathrm{~m} 3 / \mathrm{s}$ or $\mathrm{m} 3 / \mathrm{d}$; $\mathrm{Vi}$ is volume of ith reach (m3); Ei is bulk dispersion coefficient between reaches $\mathrm{i}$ and $\mathrm{i}+1, \mathrm{~m} 3 / \mathrm{d}$; Wi is external loading of the constituent to reach i, g/d or $\mathrm{mg} / \mathrm{d}$; and $\mathrm{Si}$ is sources and sinks of the constituent due to reactions and mass transfer mechanisms, g/m3/d or mg/m3/d. For bottom algae the transport and loading terms are omitted. The QUAL2K employed hydraulics based formula to determine the longitudinal dispersion for a boundary between two reaches (internally compute dispersion based on the channel's hydraulics): [5]

$$
\begin{aligned}
& \mathrm{E}_{\mathrm{p}, \mathrm{i}}=0.011 \frac{\mathrm{Bi}^{2} \cdot \mathrm{U}_{\mathrm{i}}^{2}}{\mathrm{H}_{\mathrm{i}} \cdot \mathrm{U}_{\mathrm{i}}} \\
& \mathrm{U}_{\mathrm{i}}=\sqrt{\mathrm{g} \cdot \mathrm{H}_{\mathrm{i}}} \cdot \mathrm{S}_{\mathrm{i}}
\end{aligned}
$$

where: Ep,i is the longitudinal dispersion between reaches $\mathrm{i}$ and $\mathrm{i}+1[\mathrm{~m} 2 / \mathrm{s}]$, Ui is velocity $[\mathrm{m} / \mathrm{s}]$, $\mathrm{Bi}$ is width $[\mathrm{m}], \mathrm{Hi}$ is mean depth $[\mathrm{m}]$, and $\mathrm{Ui} *$ is shear velocity $[\mathrm{m} / \mathrm{s}], \mathrm{g}$ is acceleration due to gravity $[=9.81 \mathrm{~m} / \mathrm{s} 2]$ and $S$ is channel longitudinal slope.

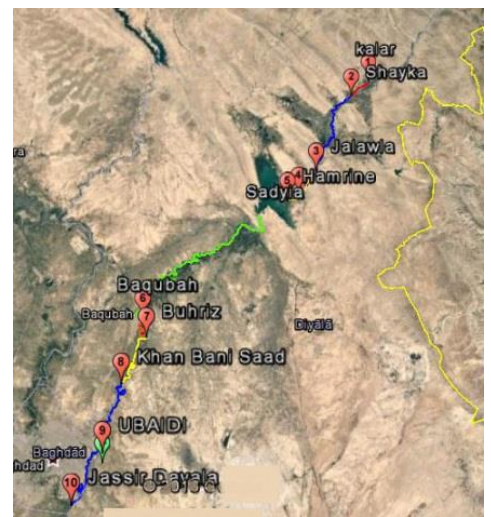

Fig. 3. Stations \& main segment of studied river.

Know to run the model there were minimum input data related with basin characteristics such as: geographic characteristics (geographical longitude and latitude, elevation), meteorological characteristics (air temperature, dew point, wind speed, cloud cover, shade), physical-chemical and biological parameters of waste water, hydraulic (morphological elements, Manning roughness coefficient, flow curve). For model calibration and verification, ten sampling stations were selected along Diyala River located within three segments of total reach namely Kalar (S1), Kan Bni Saad (S2), and Al-Zafarania (S3) as shown in Fig. 3. The technical methods used for the analysis of the sampling are summarized in Table I. The monitoring works were performed at low flow conditions for applicability of the steady flow model QUAL2K.

\section{Model Calibration}

The QUAL2K model was calibrated and confirmation using measured data, before it was used for simulating the water quality. Calibration was accomplished by adjustment of model coefficients during successive/iterative model runs, until the best goodness of fit between predicted and observed data is achieved. In general, the model was calibrated with the goal of minimizing the error for BOD and DO. Two sets of data were used for model calibration and confirmation. QUAL2K was calibrated for the month of November representing a low-flow period. The model was operated as a one-dimensional steady state and completely mixed system.

\begin{tabular}{c|c|c}
\multirow{2}{*}{$\begin{array}{c}\text { TABLE I: ANALYTICAL METHOD FOR VARIOUS PARAMETERS } \\
\text { Parameter }\end{array}$} & Units & $\begin{array}{c}\text { Instruments } \\
\text { technique used }\end{array}$ \\
\hline pH & - & Digital pH meter \\
\hline Temperature, & ${ }^{\circ} \mathrm{C}$ & $\begin{array}{c}\text { Mercury } \\
\text { Thermometer }\end{array}$ \\
\hline $\begin{array}{c}\text { Dissolved } \\
\text { oxygen }\end{array}$ & $\mathrm{mg} / \mathrm{L}$ & Winkler's method \\
\hline $\begin{array}{c}\text { Total } \\
\text { Alkalinity }\end{array}$ & $\mathrm{mg} / \mathrm{L}$ & $\begin{array}{c}\text { Winkler's method, } \\
\text { incubation for 5 days }\end{array}$ \\
\hline Electrical & $\mathrm{mg} / \mathrm{L}$ & Titration method \\
\hline
\end{tabular}

Certain geometric and hydraulic data has been obtained from and others were provided by (ERDAS 9.2 \& Global Mapper 11). Manning equation was used to express the relationship between flow and depth. The Diyala River is a natural stream channel; some reaches are clean and straight and other are clean, winding and some weeds. Thus, Manning's coefficient is taken range between 0.025 and 0.03 (Table II).

As the model simulates ultimate $\mathrm{CBOD}$, the measured 5 day CBOD (CBOD5) was transferred to ultimate CBOD $(\mathrm{CBODu})$ using the following relationship $(\mathrm{k}=$ the $\mathrm{CBOD}$ decomposition in the bottle, 1/day) [7]:

$$
\mathrm{CBOD}_{\mathrm{U}}=\frac{\mathrm{CBOD}_{\mathrm{U}}}{1-\mathrm{e}^{-5 \mathrm{k}}}
$$

The bottle rates for sewage derived organic carbons are on the order of $0.05-0.3$ day- 1 [10]. As the average COD/CBOD5 ratio was 1.83 in some part of the river [11], ratio $\mathrm{CBODu} / \mathrm{CBOD} 5$ was assumed as 1.5 , which results in rate coefficient as 0.22 . The water quality input parameters included in the model are temperature, DO, CBOD, $\mathrm{pH}$, Alkalinity and Electrical conductivity while other input parameters were not measured and the inputs were left blank. The water qualities for the wastewater and abstraction were the other point pollutions input to the model (Table 3) in which collected from various literatures. The algae and bottom sediment oxygen demand coverage were assumed $50 \%$.

\section{E. Model Parameters}

All the parameters were set as default in QUAL2K with some exception. Some of model rate parameters required by QUAL2K were obtained from QUAL2K user manual [5]. To calculate re- aeration rate, Owens-Gibbs formula [12] was 
applied. Exponential model was chosen for oxygen inhibition for CBOD oxidation, nitrification and de-nitrification. Table
IV shows the model parameters used in this study.

TABLE II: INPUT VALUES OF MANNING'S COEFFICIENT IN DIFFERENT REACH FOR RIVER

\begin{tabular}{|c|c|c|c|c|c|c|c|c|c|}
\hline \multirow{3}{*}{ Reach } & \multirow{3}{*}{ Station } & \multirow{3}{*}{$\begin{array}{l}\text { D.S. location } \\
\qquad(\mathbf{k m})\end{array}$} & \multirow{3}{*}{ Manning n } & \multicolumn{6}{|c|}{ Downstream } \\
\hline & & & & \multicolumn{3}{|c|}{ Latitude } & \multicolumn{3}{|c|}{ Longitude } \\
\hline & & & & Degrees & Minutes & Seconds & Degrees & Minutes & Seconds \\
\hline \multirow[t]{3}{*}{ S1 } & KALAR & 0 & 0.0270 & 34 & 36 & 00 & 45 & 19 & 02 \\
\hline & SHAYKA & 9.54 & 0.0300 & 34 & 32 & 26 & 45 & 15 & 32 \\
\hline & JALAWLA & 46.04 & 0.0280 & 34 & 16 & 32 & 45 & 09 & 36 \\
\hline \multirow[t]{4}{*}{ S2 } & SADIYAH & 57.34 & 0.0260 & 34 & 11 & 21 & 45 & 06 & 22 \\
\hline & HAMRINE & 62.44 & 0.0250 & 34 & 10 & 00 & 45 & 04 & 11 \\
\hline & BAQUBA & 157.74 & 0.0280 & 33 & 45 & 04 & 44 & 37 & 56 \\
\hline & BUHRIZ & 168.34 & 0.0260 & 33 & 41 & 59 & 44 & 39 & 18 \\
\hline \multirow[t]{3}{*}{ S3 } & KHAN BANI SAAD & 191.6 & 0.0270 & 33 & 13 & 17 & 44 & 30 & 19 \\
\hline & UBAIDI & 229.4 & 0.0280 & 33 & 22 & 4 & 44 & 34 & 26 \\
\hline & JASSIR & 251 & 0.0260 & 33 & 13 & 17 & 44 & 30 & 19 \\
\hline
\end{tabular}

TABLE III: THE INPUT WATER QuAlities DATA FOR HeAd WATER, POINT SOURCE AND ABSTRACTION

\begin{tabular}{|c|c|c|c|c|c|}
\hline No & Reach & Location (km) & Flow m3/s & DO mg/L & BOD mg/L \\
\hline 1 & KALAR & 0.0 & 150 & 6 & 3 \\
\hline 2 & KALAR WTP & 5.37 & 3.2 & 3.5 & 4 \\
\hline 3 & Two industrial effluent & 10.4 & 0.03 & 2.5 & 50 \\
\hline 4 & Jalawla WTP & 50.7 & 2.2 & 4.2 & 3 \\
\hline 5 & AL-Mansouria WTP & 64.3 & 3 & 3.2 & 3.5 \\
\hline 6 & Industrial effluent & 70.6 & 0.01 & 1 & 130 \\
\hline 7 & BAQUBA WTP & 166.7 & 4.37 & 4 & 4 \\
\hline 8 & Khan Bani Saad WTP & 196.3 & 4.37 & 5.5 & 5.2 \\
\hline 10 & Thermal power plant & 217 & 0.04 & 4 & 144 \\
\hline 11 & Tannery industry & 220 & 0.1 & 3 & 168 \\
\hline 12 & Pharmacy factory & 225 & 0.04 & 1.5 & 220 \\
\hline 13 & ALRUSTMIA WTP & 238 & 0.75 & 5.6 & 4 \\
\hline 14 & Group of industries & 244 & 0.2 & 3 & 160 \\
\hline
\end{tabular}

TABLE IV: MODEL PARAMETERS CONSIDERED AS INPUTS IN QUAL2K MODEL

\begin{tabular}{ccccc}
\hline Parameter & Units & Symbol & Range & Calibrated \\
\hline Temp. correction & - & & - & 1 \\
\hline O2 for carbon oxidation & $\mathrm{gO} 2 / \mathrm{gC}$ & $\mathrm{roc}$ & - & 2.69 \\
\hline O2 for NH4 nitrification & $\mathrm{gO} 2 / \mathrm{gN}$ & $\mathrm{ron}$ & - & 4.57 \\
\hline Oxygen inhib CBOD oxidation & $\mathrm{L} / \mathrm{mgO} 2$ & $\mathrm{Ksocf}$ & - & 0.60 \\
\hline Oxygen inhib nitrification parameter & $\mathrm{L} / \mathrm{mgO} 2$ & $\mathrm{Ksona}$ & - & 0.60 \\
\hline CBOD Hydrolysis rate & $/ \mathrm{d}$ & $\mathrm{khc}$ & $0.02-5.6$ & 2 \\
\hline CBOD Oxidation rate & $/ \mathrm{d}$ & $\mathrm{kdc}$ & $0.02-5.6$ & 4 \\
\hline Partial pressure of carbon dioxide & $\mathrm{ppm}$ & $\mathrm{Pco} 2$ & - & 347 \\
\hline Photosynthetically Available Radiation & - & - & - & 0.47 \\
\hline Background light extinction & $/ \mathrm{m}$ & - & - & 0.2 \\
\hline Linear chlorophyll light extinction & $1 / \mathrm{m}-(\mathrm{ugA} / \mathrm{L})$ & $\mathrm{ap}$ & - & 0.0088 \\
\hline
\end{tabular}

\section{F. Model Validation}

Two sets of data were used for model calibration and validation. After giving all inputs, a number of trials were made to ensure matching of observed and simulated values of BOD and DO. Errors in simulations are estimated as the difference between models forecasted values and observed data. The relative error for BOD was $23 \%, 14 \% \& 4 \%$ at Kalar city (S1), Sadiyah city(S2), and Al-Zafarania district (S3) respectively while for DO was $10 \%, 15 \% \& 11 \%$ at Kalar city (S1), Sadiyah city(S2), and Al-Zafarania district (S3) respectively. 


\section{RESUlTS AND DisCUSSIONS}

The results for the water quality parameters that used as input data for head water are shown in Table 5 while Table 6 shows the measurement data in different stations along river for comparison with predicted values.

\begin{tabular}{|c|c|c|}
\hline Parameters & Unit & $\begin{array}{c}\text { Head water } \\
\text { (Kalar) }\end{array}$ \\
\hline Temperature & ${ }^{\circ} \mathrm{C}$ & 8 \\
\hline $\mathrm{pH}$ & - & 7.2 \\
\hline Electrical conductivity & $\mu \mathrm{s} / \mathrm{cm}$ & 750 \\
\hline Dissolved Oxygen & $\mathrm{mg} / \mathrm{L}$ & 6 \\
\hline BOD & $\mathrm{mg} / \mathrm{L}$ & 3 \\
\hline Total Alkalinity & $\mathrm{mg} / \mathrm{L}$ & 120 \\
\hline
\end{tabular}

From model output (Fig. 4), it can be seen that DO concentrations for the entire river are meet the targeted quality criteria for survival of fisheries: minimum DO at or above $4 \mathrm{mg} / \mathrm{L}$. In case of CBOD (Fig. 5), it can be noticed that the Diyala River CBOD could be divided into three main reaches; the first one is extended from $\operatorname{Kalar}(0 \mathrm{~km})$ to Jalawla $(46 \mathrm{~km})$ and the second one begin from Sadyia and extend to near Buhriz. The third reach extends from Khan Bani Saad city to Al-jussir in the south at river confluence with Tigris River which has CBOD concentrations.

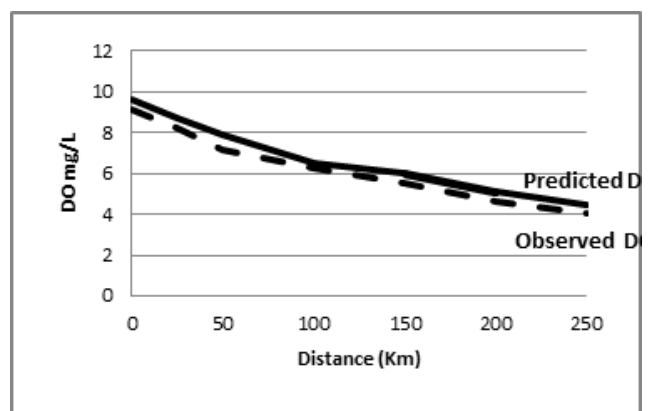

Fig. 4. The confirmation results in Nov. comparison of observed DO.

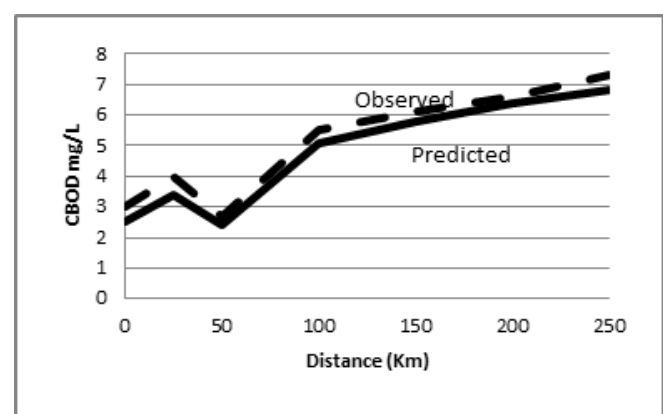

Fig. 5. The confirmation results in Nov. comparison of observed and predicted CBOD.

\begin{tabular}{|c|c|c|c|c|c|}
\hline No & Reach & $\begin{array}{c}\text { Location } \\
\text { km } \\
(\mathbf{k m})\end{array}$ & $\begin{array}{l}\text { BOD mg/L } \\
1^{\text {st }} \text { case }\end{array}$ & $\begin{array}{l}\text { BOD mg/L } \\
2^{\text {nd }} \text { case }\end{array}$ & $\begin{array}{c}\text { BOD } \mathrm{mg} / \mathrm{L} \\
3^{\text {rd }} \text { case }\end{array}$ \\
\hline 1 & KALAR & 0.0 & 2 & 2 & 2 \\
\hline 2 & KALAR WTP & 5.37 & 2.3 & 2.3 & 2.3 \\
\hline 3 & Two industrial effluent & 10.4 & 70 & 50 & 30 \\
\hline 4 & Jalawla WTP & 50.7 & 2 & 2 & 2 \\
\hline 5 & AL-Mansouria WTP & 64.3 & 2 & 2 & 2 \\
\hline 6 & Industrial effluent & 70.6 & 70 & 50 & 30 \\
\hline 7 & BAQUBA WTP & 166.7 & 4 & 4 & 4 \\
\hline 8 & Khan Bani Saad WTP & 196.3 & 5.2 & 5.2 & 5.2 \\
\hline 9 & Thermal power plant & 217 & 70 & 50 & 30 \\
\hline 10 & Tannery industry & 220 & 70 & 50 & 30 \\
\hline 11 & Pharmacy factory & 225 & 70 & 50 & 30 \\
\hline 12 & ALRUSTMIA WTP & 238 & 70 & 50 & 30 \\
\hline 13 & Group of industries & 244 & 4 & 4 & 4 \\
\hline 14 & KALAR & 0.0 & 70 & 50 & 30 \\
\hline
\end{tabular}

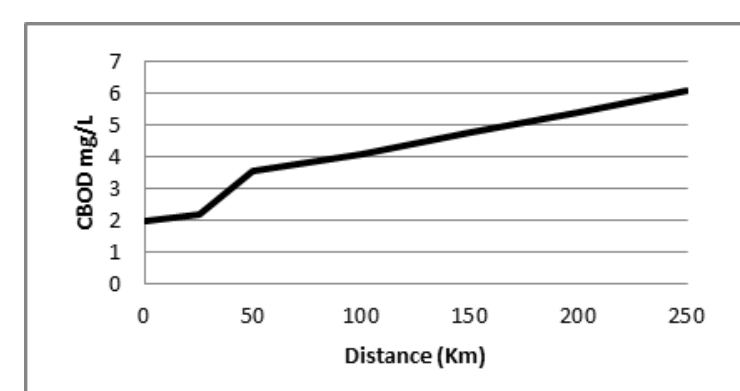

Fig. 6. CBOD concentrations along Diyala River in case of control the discharges of point sources as $70 \mathrm{mg} / \mathrm{L}$ BOD.

The high level of CBOD in the third reach of the river may due to discharges of untreated wastewater from different point sources. At $50 \mathrm{~km}$ distance near Jalawla city bridge, it can be readily seen that CBOD level slightly decreases due to self-purification of the river. In general, The Diyala River upstream of Jalwla Bridge is not heavily polluted organically. The most polluted zone in the river located downstream of Khan Bani Saad city because of the discharge of pollutants. In case of dissolved oxygen, the DO in surface water should not be less $4 \mathrm{mg} / \mathrm{L}$; the entire Diyala River is within standard of $4 \mathrm{mg} / \mathrm{L}$. the low DO concentration in headwater may due to agricultures activities upstream of Kalar city (Fig. 6).

\section{CONCLUSIONS}

A stream water quality model, QUAL2K, was calibrated for the Diyala River through assessment of phsico-chemical parameters and using the data collected from several literatures. The model was applied to simulate the dissolved 
oxygen (DO) and biochemical oxygen demand (CBOD5) profiles of the river during low flow period. Remote sensing \& GIS techniques were also used to provide some QUAL2K input data that related with Diyala River geometric and hydraulic characteristics. From model results, it can be concluded that the river water is within the standard quality criteria of DO above $4 \mathrm{mg} / \mathrm{L}$. The third reach of the river which begins from Khan Bani Saad and extends to AlZafarania is the most polluted reach in the river. From strategy 1 , it could be stated that authorities should monitors the industries that discharged their effluent without adequate treatment to the river and BOD in the discharged effluent should be kept at least $50 \mathrm{mg} / \mathrm{L}$ to maintain BOD below 4 $\mathrm{mg} / \mathrm{L}$ in the Diyala river water. Strategy 2 (flow augmentation) does not gave significant. vision. Water quality modeling provides better understanding of the physical and chemical processes. Since, models are able to realistically represent surface waters; they can be used to support water quality management and decision-making. This reasonable modeling application guarantees the use of QUAL2K for future river water quality policy options.

\section{REFERENCES}

[1] E. J. Abdullah, "Evaluation of surface water quality indices for heavy metals of Diyala River-Iraq," Evaluation, Baghdad: University of Baghdad, 2013.

[2] L. C. Brown and T. O. Barnwell, "The enhanced stream water quality models QUAL2E and QUAL2E-UNCAS: Documentation and user manual," USEPA, Environmental Research Laboratory, Athens: GA, 1987.

[3] S. S. Park and C. G. Uchrin, "Water quality modelling of the lower south branch of the Raritan River," New Jersey Academy of Science, vol. 35 , pp. 17-23, 1990.
[4] S. S. Park and C. G. Uchrin, "Waste load allocation for macrophyte growing impoundment: A combined modelling approach," J. Environ. Journal of Science and Health, vol. 35, pp. 411-28, 1996.

[5] S. C. Chapra and G. J. Pelletier, QUAL2K: A Modelling Framework for Simulating River and Stream Water Quality (Beta Version): Documentation and User's Manual, Civil and Environmental Engineering Dept., Tufts University, 2003.

[6] R. Paliwal et al., "Water quality modelling of the river Yamuna (India) using QUAL2E-UNCAS," Journal of Environmental Management, vol. 83, pp. 131-144, 2006.

[7] P. R. Kannel et al., "Application of automated QUAL2K for water quality modelling and management in the Bagmati River, Nepal," Ecological Modelling, pp. 503-517, 2007.

[8] A. Al-Shami et al., "Evaluation of environmental impact of Diyala river pollution (between Jadirriya and dora bridges)," Journal of Engineering, vol. 3, pp. 844-861, 2006.

[9] G. J. Pelletier et al., "QUAL2Kw, A framework for modeling water quality in streams and rivers using a genetic algorithm for calibration," Environ. Model. Software," vol. 21, pp. 419-4125, 2006.

[10] O. S. Al-Timemi, "Assessment of water resources in Diyala River basin- middle part," Ph.D. thesis, Univ. of Baghdad, Baghdad: College of Science, p.165, 2007.

[11] N. Al-Ansari and M. Al-Jabbari, "Hemrin reservoir, geological and hydrological investigation," Journal of Water Res., Special Publ., vol. 2, p. 2, 1987

[12] M. Owens et al., "Some reaeration studies in streams," Int. J. Air Water Pollut., vol. 8, pp. 469-486, 1964.

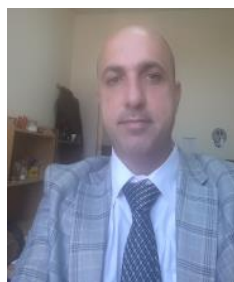

Ghassan AL-Dulaimi was born on October 21, 1973, in Iraq, Baghdad. He got the PhD in civil engineering water resources from University of technology Baghdad, Iraq. He works as associate professor in Philadelphia University Jordan, Amman 